\title{
The Effect of Glucose on Urinary Cation Excretion during Chronic Extracellular Volume Expansion
} in Normal Man

\author{
Edward J. Lennon, J. Lemann, Jr., W. F. Piering, and L. S. Larson \\ From the Renal Section, Department of Medicine, Medical College of \\ Wisconsin and the Clinical Research Center, Milwaukee County General \\ Hospital, Milwaukee, Wisconsin 53226
}

\begin{abstract}
A B S T R A C T Both glucose administration and extracellular volume expansion augment urinary calcium and magnesium excretion. While volume expansion also augments sodium excretion, glucose induces an antinatriuresis. To examine the interrelationships of volume expansion and of glucose administration on sodium, calcium, and magnesium excretion, the effects of glucose were evaluated during clearance studies in the same subjects before and after chronic extracellular volume expansion produced by desoxycorticosterone acetate (DOCA) and a normal dietary sodium intake. The augmentation of $U_{C_{2}} V$ and $U_{M_{g} V}$ by glucose was simply additive to the increments in divalent cation excretion caused by "escape" from the sodium-retaining effects of DOCA. Glucose administration reduced $U_{\mathrm{Na}} V$, an effect exaggerated after DOCA escape and associated with reductions in volume/glomerular filtration rate (V/GFR) and $\mathrm{C}_{\mathrm{N} z}+\mathrm{C}_{\mathrm{H}_{2} \mathrm{O}} / \mathrm{GFR}$, suggesting augmented proximal tubular reabsorption. Before glucose, $\mathrm{U}_{\mathrm{Na}}$ was inversely correlated with $\mathrm{U}_{\mathrm{a}}$, and after glucose administration $\mathrm{C}_{\mathrm{N}_{a}} / \mathrm{GFR}$ was inversely correlated with $\mathrm{T}_{\mathrm{o}} / \mathrm{GFR}$. We propose that the availability of glucose in the proximal tubule stimulates $\mathrm{Na}$ reabsorption while delaying development of a chloride diffusion potential, thereby inhibiting tubular reabsorption of $\mathrm{Ca}$ and $\mathrm{Mg}$.
\end{abstract}

\section{INTRODUCTION}

Glucose administration has been shown to augment urinary calcium and magnesium excretion $(1,2)$. This effect is clearly due to reduced net tubular reabsorption of

Part of this work was published in abstract (J. Clin. Invest., 1971. 50: 59a).

Received for publication 9 July 1973 and in revised form 22 October 1973. these divalent cations ( 3 ), and in a previous study we presented evidence suggesting that this inhibition of reabsorption might occur, in part, in the distal tubule (4). However, since a large fraction of filtered sodium and calcium is reabsorbed proximally, and most physiologic stimuli alter proximal reabsorption of sodium and calcium in the same direction, the finding that glucose ingestion augments proximal sodium reabsorption $(5,6)$ made it difficult to accept an effect of glucose to inhibit calcium reabsorption in the distal tubule as a complete explanation for the observed calciuresis. The present experiments were designed to examine the effect of glucose on these interrelationships under circumstances in which urinary excretion rates of sodium as well as calcium and magnesium are increased $(7-10)$, and in which proximal tubular sodium reabsorption is reportedly inhibited (11), i.e. during chronic volume expansion induced by desoxycorticosterone acetate (DOCA) ${ }^{1}$ administration.

\section{METHODS}

Studies were carried out on 10 healthy men, with their informed consent, in the Medical College of Wisconsin Clinical Research Center. Each subject ate a constant normal diet (average composition shown in Table I) and 24-h urine specimens were collected except during days of clearance studies. After 5-10 control days, after overnight fasting, and during water diuresis, clearances of serum ultra-

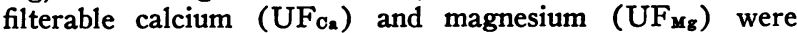
measured during three or four 20-min control clearance periods and during six subsequent 20 -min clearance periods after glucose administration. Water diuresis was induced

${ }^{1}$ Abbreviations used in this paper: C, clearance. rate; DOCA, desoxycorticosterone acetate; ECF, extracellular fluid; G, glucose; GFR, glomerular filtration rate; In, inulin; $\mathrm{T}$, tubular reabsorption; $\mathrm{U}$, urinary concentrations; $\mathrm{UF}$, ultrafilterable. 


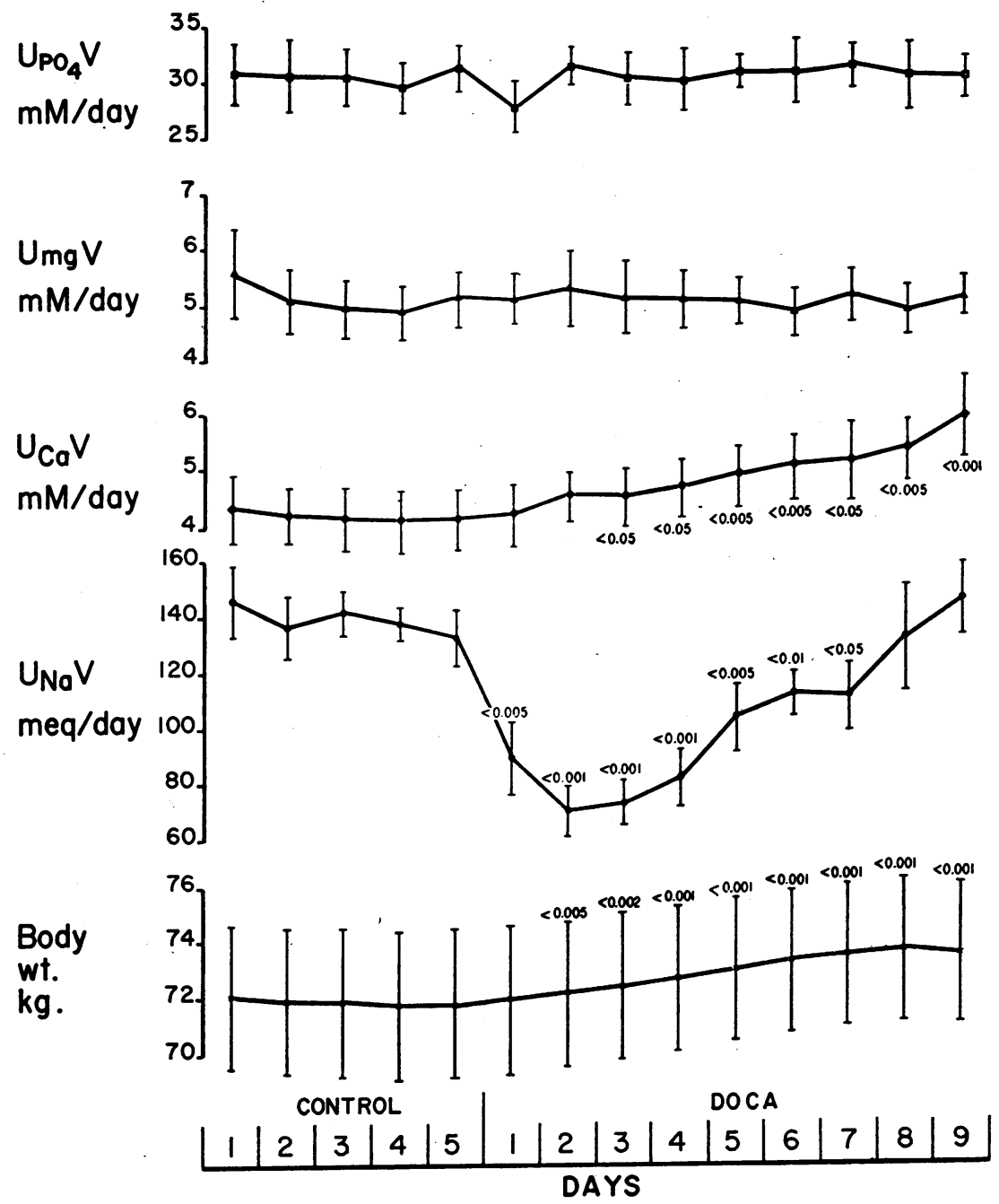

FIGURE 1 Mean daily urinary excretion rates of $\mathrm{PO}_{4}, \mathrm{Mg}, \mathrm{Ca}$, and $\mathrm{Na}$, and mean daily body weight during control and during DOCA administration. Vertical lines indicate \pm SEM. $P$ values are for mean of individual changes from control during DOCA.

by the ingestion of $20 \mathrm{ml}$ of water $/ \mathrm{kg}$ body wt and sustained by continuing water ingestion to match urinary losses. DOCA, $10 \mathrm{mg}$ i.m. twice daily was then begun and continued beyond escape from the sodium-retaining effects of the hormone as defined by return of daily urinary sodium excretion to or above individual control rates and stabilization of body weight. A second escape clearance study, identical to the first, was then carried out. Each subject received his final dose of DOCA immediately before this second clearance study. All clearance studies began at 0700 to control for normal diurnal variation in urine composition. After the control clearance periods, seven subjects received $100 \mathrm{~g}$ glucose orally during both control and escape clearance studies. To control for any possible effect of the hyperosmotic oral glucose load on intestinal fluxes, three additional subjects received after their control periods, 0.2 $\mathrm{g}$ glucose $/ \mathrm{kg}$ and $10 \mathrm{mU}$ insulin $/ \mathrm{kg}$ as an i.v. priming dose followed by $0.6 \mathrm{~g}$ glucose $/ \mathrm{min}$ and $1 \mathrm{mU}$ insulin $/ \mathrm{kg}$ per. $\mathrm{min}$ i.v. throughout their remaining clearance periods (total glucose $85-94 \mathrm{~g}$ and total insulin 9.1-11.8 U). While the total glucose load was similar in the two groups, the peak plasma glucose occurred earlier in the subjects given glucose i.v. and the mean increment in plasma glucose (determined by graphic integration of the area under the curve) was slightly but not significantly lower (oral glucose +2.86 $\pm 0.35 \mathrm{SE} \mathrm{mM} /$ liter; i.v. glucose plus insulin $+1.58 \pm 0.53$

TABLE I

Mean Daily Diet Composition

\begin{tabular}{lc}
\hline $\mathrm{Na}, m M$ & $151 \pm 1$ \\
$\mathrm{~K}, m M$ & $87 \pm 3$ \\
$\mathrm{Ca}, m M$ & $24.9 \pm 0.2$ \\
$\mathrm{Mg}, m M$ & $13.4 \pm 0.5$ \\
$\mathrm{Cl}, m M$ & $146 \pm 3$ \\
$\mathrm{P}, m M$ & $58 \pm 2$ \\
\hline
\end{tabular}


TABLE 11

Control Clearance Measurements before and after DOCA "Escape"

\begin{tabular}{|c|c|c|c|c|c|c|c|c|c|}
\hline \multicolumn{5}{|c|}{ Blood } & \multicolumn{5}{|c|}{ Urine } \\
\hline & Control & $\begin{array}{l}\text { DOCA } \\
\text { Escape }\end{array}$ & $\Delta$ & $\boldsymbol{P}$ & & Control & $\begin{array}{c}\text { DOCA } \\
\text { Escape }\end{array}$ & $\Delta$ & $\boldsymbol{P}$ \\
\hline $\mathrm{H}^{+}$, neq $/$liter & $38.9 \pm 1.1$ & $38.6 \pm 1.1$ & $-0.3 \pm 1.1$ & NS & $\mathrm{V}, m l / \min$ & $13.8 \pm 1.0$ & $16.8 \pm 0.8$ & $+3.1 \pm 1.1$ & $<0.05$ \\
\hline$\left[\mathrm{HCO}_{3}^{-}\right]$, meq/liter & $26.8 \pm 0.6$ & $29.0 \pm 0.4$ & $+2.2 \pm 0.5$ & $<0.005$ & Uosmol & $63 \pm 4$ & $73 \pm 6$ & $\pm 10 \pm 5$ & NS \\
\hline $\mathrm{pCO}_{2}, \mathrm{~mm} \mathrm{Hg}$ & $43.7 \pm 1.6$ & $46.8 \pm 1.2$ & $+3.1 \pm 1.2$ & $<0.02$ & $\mathrm{U}_{\mathrm{N}} \mathrm{V}, \mu M / \min$ & $141 \pm 18$ & $370 \pm 52$ & $+229 \pm 49$ & $<0.002$ \\
\hline$[\mathrm{Na}], m M / l i t e r$ & $137 \pm 1$ & $142 \pm 1$ & $+5 \pm 1$ & $<0.001$ & $\mathrm{UkV}, \mu M / \min$ & $76 \pm 8$ & $59 \pm 5$ & $-17 \pm 8$ & NS \\
\hline$[\mathrm{K}], \mathrm{mM} /$ liter & $4.0 \pm 0.1$ & $3.4 \pm 0.1$ & $-0.6 \pm 0.1$ & $<0.001$ & $\mathrm{U} \mathrm{caV}_{\mathrm{aV}} \mu M / \min$ & $3.02 \pm 0.56$ & $6.76 \pm 0.91$ & $+3.74 \pm 0.63$ & $<0.001$ \\
\hline Total $[\mathrm{Ca}], m M / l i t e r$ & $2.28 \pm 0.03$ & $2.21 \pm 0.03$ & $-0.07 \pm 0.02$ & $<0.02$ & $\mathrm{U}_{M_{\mathrm{g}} \mathrm{V}, \mu M / \min }$ & $3.09 \pm 0.43$ & $4.56 \pm 0.43$ & $+1.47 \pm 0.36$ & $<0.005$ \\
\hline $\mathrm{UFc}_{\mathrm{a}}, \mathrm{mM} / \mathrm{liter}$ & $1.43 \pm 0.02$ & $1.41 \pm 0.02$ & $-0.02 \pm 0.02$ & NS & $\mathrm{H}^{+}$, neq/liter & $354 \pm 70$ & $133 \pm 30$ & $-221 \pm 64$ & $<0.01$ \\
\hline Total $[\mathrm{Mg}], m M / l i$ iter & $0.81 \pm 0.02$ & $0.84 \pm 0.02$ & $+0.03 \pm 0.02$ & NS & $\mathrm{pH}$ & 6.45 & 6.88 & +0.43 & \\
\hline $\mathrm{UF}_{\mathbf{M g}_{\mathrm{g}}, m M / l i t e r}$ & $0.60 \pm 0.01$ & $0.63 \pm 0.01$ & $+0.03 \pm 0.02$ & NS & $\mathrm{UHCO}_{3} \mathrm{~V}, \mu \mathrm{eq} / \min$ & $38 \pm 9$ & $107 \pm 15$ & $+69 \pm 17$ & $<0,005$ \\
\hline$[\mathrm{Cl}], m M /$ liter & $101 \pm 1$ & $104 \pm 1$ & $+3 \pm 1$ & $<0.005$ & $\mathrm{UNH}_{4}+\mathrm{V}, \mu \mathrm{eq} / \mathrm{min}$ & $38 \pm 3$ & $32 \pm 4$ & $-5 \pm 3$ & NS \\
\hline POA, $m M /$ liter & $1.15 \pm 0.05$ & $1.07 \pm 0.03$ & $-0.08 \pm 0.05$ & NS & $\mathrm{UTAV}_{\mathrm{TA}}$, $\mathrm{eq} / \mathrm{min}$ & $6 \pm 1$ & $4 \pm 1$ & $-2 \pm 1$ & NS \\
\hline Glucose, $m M /$ liter & $4.56 \pm 0.11$ & $4.50 \pm 0.11$ & $-0.06 \pm 0.06$ & NS & UNet AoidV, $\mu \mathrm{eq} / \mathrm{min}$ & $+6 \pm 11$ & $-71 \pm 18$ & $-77 \pm 20$ & $<0.005$ \\
\hline Osm, mosmol/kg & $285 \pm 2$ & $290 \pm 1$ & $+5 \pm 3$ & NS & $\mathrm{U}_{\mathrm{C}_{\mathrm{V}} \mathrm{V}, \mu M / \min }$ & $154 \pm 18$ & $289 \pm 40$ & $+135 \pm 34$ & $<0.005$ \\
\hline \multirow{6}{*}{ Pures, $m M /$ liter } & $4.2 \pm 0.4$ & $3.3 \pm 0.2$ & $-0.9 \pm 0.2$ & $<0.001$ & $\mathrm{UPO}_{4} \mathrm{~V}, \mu M / \min$ & $12.4 \pm 1.1$ & $16.4 \pm 1.6$ & $+4.0 \pm 1.2$ & $<0.02$ \\
\hline & & & & & Ua luoose $\mathrm{V}, \mu M / \min$ & $0.52 \pm 0.05$ & $0.83 \pm 0.09$ & $+0.31 \pm 0.12$ & $<0.05$ \\
\hline & & & & & Uosm V, $\mu$ osmol/min & $849 \pm 55$ & $1205 \pm 90$ & $+356 \pm 87$ & $<0.005$ \\
\hline & & & & & UUrosV, $\mu M / \min$ & $339 \pm 25$ & $313 \pm 25$ & $-26 \pm 6$ & $<0.005$ \\
\hline & & & & & Uso4V, meq/min & $25 \pm 2$ & $24 \pm 1$ & $-1 \pm 2$ & NS \\
\hline & & & & & $\begin{array}{l}\text { UTotal Org. AoidsV, } \\
\text { meg/min }\end{array}$ & $97 \pm 10$ & $102+6$ & $+5 \pm 8$ & NS \\
\hline
\end{tabular}

$\mathrm{mM} /$ liter ; $t=0.58, \mathrm{NS}$ ). Despite these temporal and quantitative differences the relation between tubular glucose reabsorption and cation excretion was quantitatively similar for the two groups (see Fig. 7 and Discussion). Thus the data for the two groups have been pooled.

Urinary glucose was measured by a glucose oxidase technique (12) modified to provide sensitivity to concentrations as low as $0.01 \mathrm{mM} /$ liter. The other analytical techniques utilized have been previously reported (13). Volume/glomerular filtration rate (V/GFR), $\mathrm{C}_{\mathrm{urea}} / \mathrm{GFR}$ and $\mathrm{C}_{\mathrm{Na}}+$ $\mathrm{C}_{\mathrm{H}_{2} \mathrm{O}} / \mathrm{GFR}$ were used as estimates of fractional filtrate delivery to the diluting sites, and $\mathrm{C}_{\mathrm{H}_{2} \mathrm{O}} / \mathrm{V}$ as an estimate of fractional sodium reabsorption in the diluting segments of the nephron. Results are presented as means \pm standard error of the mean, and changes have been evaluated by Student's $t$ test for paired differences.

\section{RESULTS}

Effects of DOCA administration on body weight and urine composition. As shown in Fig. 1, body weight and urinary excretion rates of $\mathrm{Na}, \mathrm{Ca}, \mathrm{Mg}$, and $\mathrm{PO}_{4}$ were stable during the control period. Potassium and chloride excretion rates (not shown) were also steady. After DOCA administration was begun, sodium retention persisted for an average of 8 days, during which body weight increased progressively. Thereafter, urinary sodium excretion returned to control rates and body weight stabilized. On the average, the subjects retained $336 \pm 51$ meq of sodium before escape, which would predict a mean weight gain of $2.24 \mathrm{~kg}$ (assuming $1 \mathrm{~kg}$ gain for $150 \mathrm{meq} \mathrm{Na}$ retained). Measured weight changes were in good agreement, averaging $+2.23 \pm 0.45 \mathrm{~kg}$, a $3.1 \%$ increase in body weight. During DOCA administration, chloride retention paralleled that of sodium, while po- tassium excretion increased as expected (not shown in the figure). As the volume of extracellular fluid (ECF) became progressively expanded, urinary calcium excretion rose steadily, while daily magnesium and phosphorus excretions were unaffected.

Effect of chronic volume expansion on blood and urine composition and tubular function. Table II compares the mean values for measured blood and urine constituents during the clearance periods before glucose administration in the normal steady state with the same periods after escape from DOCA. Table III compares derived clearance calculations for the same periods. As shown in Table II, after DOCA escape, mild, compensated metabolic alkalosis, hypokalemia, hypernatremia, and hyperchloremia, all typical of the response to mineralocorticoid excess, were present. Total serum calcium concentrations were slightly but significantly reduced, presumably because of dilution of the proteinbound moiety. Serum urea concentrations were reduced. The remaining serum and serum-ultrafiltrate constituents did not change.

Despite constant diets and identical water loads, urine flow rates were higher during the escape studies. Urinary excretion rates of $\mathrm{Na}, \mathrm{Ca}, \mathrm{Mg}, \mathrm{Cl}, \mathrm{PO}_{4}$, glucose, bicarbonate, and total solute were increased, while urinary osmolalities were similar. Since not all of these effects were apparent in the 24-h urine collections (see Fig. 1), we infer that the augmentation of water and solute excretion that follows water loading may be exaggerated during chronic volume expansion. 
TABLE III

Derived Clearance Data for Control Clearance Periods before and after "DOCA Escape"

\begin{tabular}{lcccc}
\hline & Control & DOCA & $\Delta$ & $P$ \\
\hline $\mathrm{C}_{\text {Inulin }}$ & $113 \pm 4$ & $123 \pm 4$ & $+10 \pm 4$ & $<0.02$ \\
$\mathrm{E} / \mathrm{F} \mathrm{Na}$ & $0.91 \pm 0.11$ & $2.15 \pm 0.30$ & $+1.24 \pm 0.27$ & $<0.002$ \\
$\mathrm{E} / \mathrm{F} \mathrm{Cl}$ & $1.35 \pm 0.15$ & $2.30 \pm 0.34$ & $+0.95 \pm 0.27$ & $<0.01$ \\
$\mathrm{C}_{\text {osm }} / \mathrm{GFR}$ & $2.62 \pm 0.17$ & $3.42 \pm 0.28$ & $+0.80 \pm 0.24$ & $<0.01$ \\
$\mathrm{E} / \mathrm{F} \mathrm{Ca}$ & $1.85 \pm 0.32$ & $3.90 \pm 0.44$ & $+2.05 \pm 0.31$ & $<0.001$ \\
$\mathrm{C}_{\mathrm{Ca}} / \mathrm{C}_{\mathrm{Na}}$ & $2.26 \pm 0.43$ & $1.97 \pm 0.22$ & $-0.28 \pm 0.33$ & $\mathrm{NS}$ \\
$\mathrm{E} / \mathrm{F} \mathrm{Mg}$ & $4.49 \pm 0.54$ & $5.88 \pm 0.43$ & $+1.39 \pm 0.5$ & $<0.05$ \\
$\mathrm{C}_{\mathrm{M}_{\mathrm{g}}} / \mathrm{C}_{\mathrm{Na}}$ & $5.83 \pm 1.08$ & $3.04 \pm 0.26$ & $-2.78 \pm 0.98$ & $<0.02$ \\
$\mathrm{E} / \mathrm{F} \mathrm{PO}$ & $9.9 \pm 1.1$ & $12.3 \pm 1$ & $+2.4 \pm 0.8$ & $<0.05$ \\
$\mathrm{E} / \mathrm{F} \mathrm{HCO}$ & $1.23 \pm 0.30$ & $2.94 \pm 0.35$ & $+1.71 \pm 0.47$ & $<0.01$ \\
$\mathrm{E} / \mathrm{F} \mathrm{Glucose}$ & $0.10 \pm 0.01$ & $0.15 \pm 0.02$ & $+0.05 \pm 0.02$ & $<0.05$ \\
$\mathrm{~V} / \mathrm{GFR}$ & $12.1 \pm 0.7$ & $14.1 \pm 0.6$ & $+2.0 \pm 0.8$ & $<0.05$ \\
$\mathrm{C}_{\mathrm{H}_{2} \mathrm{O}}+\mathrm{C}_{\mathrm{Na}_{\mathrm{a}}} / \mathrm{GFR}$ & $10.4 \pm 0.7$ & $12.6 \pm 0.6$ & $+2.1 \pm 0.9$ & $=0.05$ \\
$\mathrm{C}_{\mathrm{urea}} / \mathrm{GFR}$ & $74 \pm 3$ & $79 \pm 3$ & $+5 \pm 2$ & $<0.02$ \\
$\mathrm{C}_{\mathrm{H}_{2} \mathrm{O}} / \mathrm{V}$ & $78 \pm 2$ & $76 \pm 2$ & $-2 \pm 2$ & $\mathrm{NS}$ \\
\hline
\end{tabular}

After escape from DOCA, the urine was significantly less acid and net renal acid excretion fell because of increased rates of bicarbonate excretion (Table II). Table III shows that GFR (Cinu1n) and the fractional excretion rates of $\mathrm{Na}, \mathrm{Cl}$, total solute, $\mathrm{Ca}, \mathrm{Mg}, \mathrm{PO}$, $\mathrm{HCO}_{3}^{-}$, and glucose were higher after escape from DOCA. Fractional excretion of calcium was increased in proportion to that of sodium, since the ratio $\mathrm{C}_{\mathrm{c}} / \mathrm{C}_{\mathrm{Na}}$ did not change. The increase in fractional magnesium excretion, although statistically significant, was small and the ratio $\mathrm{C}_{\mathbf{x}_{\mathrm{g}}} / \mathrm{C}_{\mathrm{Na}}$ actually fell.

$\mathrm{V} / \mathrm{GFR}, \mathrm{C}_{\mathrm{Na}}+\mathrm{C}_{\mathrm{H} z \mathrm{O}} / \mathrm{GFR}$, and $\mathrm{C}_{\mathrm{urea}} / \mathrm{GFR}$ all increased after escape, suggesting (in agreement with augmented fractional excretion rates of phosphate and glucose) increased delivery of glomerular filtrate from proximal nephron segments. No change in sodium reabsorption in diluting segments was discernable, as judged from unaltered $\mathrm{C}_{\mathrm{H}_{2}} / \mathrm{V}$.

The effects of glucose before and after chronic ECF volume expansion. Table IV summarizes the changes in measured blood constituents that occurred after glucose ingestion during the clearance studies done before DOCA administration. Glucose tolerance was normal. Serum potassium and phosphate concentration fell as expected. Serum chloride and total solute concentrations rose while serum urea concentrations fell. Total serum calcium concentrations fell. Other measured blood constituents were unaffected (Table II). The changes in blood composition after glucose loading during the escape clearances were quantitatively identical and of similar statistical significance.

Table $\mathrm{V}$ summarizes the changes in renal excretory rates that followed glucose ingestion in the clearances carried out before DOCA administration. Urine flow rates declined slightly, but not significantly, and the urine remained dilute. Urinary sodium excretion fell, but the decline was not statistically significant. Potassium excretion fell significantly. Urinary calcium and magnesium excretion rates rose significantly. The urine was acidified and net acid excretion rose as a result of increments in titratable acid and ammonium excretion and decrements in bicarbonate excretion. Chloride excretion fell in parallel to that of sodium. Phosphate excretion rose transiently and then returned to control rates. Glucose excretion rose. Total solute excretion fell but the decline did not reach statistical significance because of variation among subjects. Urea and inorganic sulfate excretion did not change while organic anion excretion rates tended to rise. GFR ( $\left.\mathrm{C}_{t n}\right)$ rose, reaching rates significantly above control in the final two clearance periods after glucose.

The changes in urine composition after glucose ingestion during chronic volume expansion were similar with some quantitative differences. After escape (Fig. 2), glucose loading induced a lesser degree of urinary acidification, a greater reduction in bicarbonate excretion, but equivalent increments in titratable acid and ammonium excretion, resulting in a greater increase in net acid excretion. Potassium excretion fell only transiently and to a lesser extent.

Figs. 3, 4, and 5 compare additional data for the clearances before and after DOCA escape. As shown in Fig. 3, glucose tolerance was normal in both phases of the study. The biphasic rise in fractional glucose excretion resulted from combining the results for the seven subjects who ingested glucose and the three subjects who received glucose and insulin intravenously. Fractional phosphate excretion rose promptly but transi- 

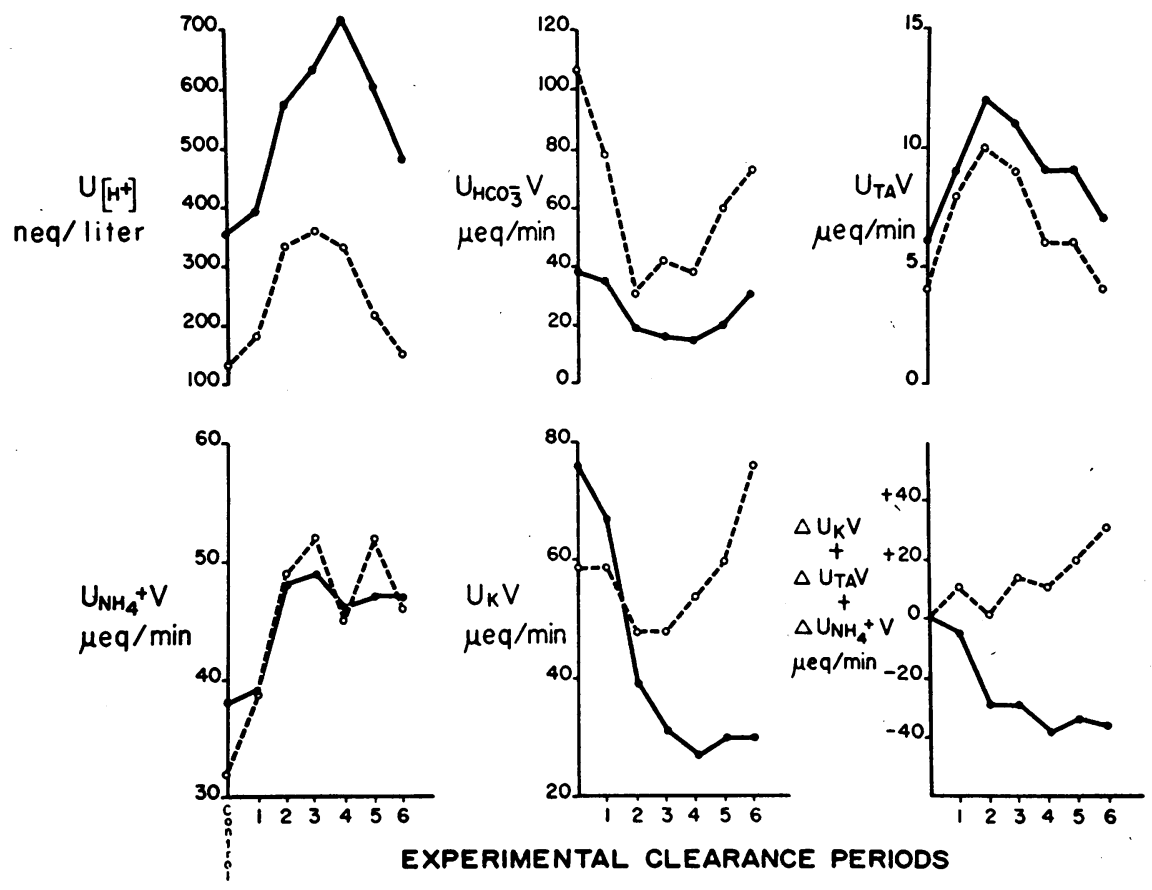

Figure 2 Mean urine $\left[\mathrm{H}^{+}\right]$and urinary excretion rates of $\mathrm{HCO}_{3}$, titratable acid (TA), $\mathrm{NH}_{4}^{+}, \mathrm{K}^{+}$, and the sum of the changes in excretion rates of $\mathrm{K}^{+}+\mathrm{TA}+\mathrm{NH}_{4}^{+}$during control

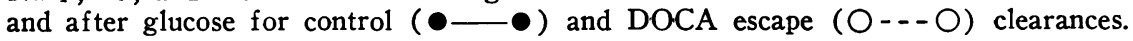

ently in each study, returning to control in the periods 60-120 min after glucose. Fractional bicarbonate excretion fell to a greater extent in the escape studies $(P<$ 0.02 ).

Fig. 4 shows that fractional excretion rates of calcium and magnesium increased after glucose loading, the increments being similar before and after chronic volume expansion. The increments in divalent cation ex- cretion occurred despite simultaneous reductions in fractional sodium excretion. Fractional sodium excretion was reduced to a greater extent during the DOCA escape studies $(P<0.05)$.

As shown in Fig. 5, the urine was similarly dilute before and during chronic volume expansion and remained so after glucose loading. In response to glucose administration, V/GFR and $\mathrm{C}_{\mathrm{Na}}+\mathrm{C}_{\mathrm{H}_{2} \mathrm{O}} / \mathrm{GFR}$ fell, but this was

TABLE IV

Blood Composition before and after Glucose during Control Clearances

\begin{tabular}{|c|c|c|c|c|c|c|c|}
\hline & Control mean & 1 & 2 & 3 & 4 & 5 & 6 \\
\hline $\begin{array}{l}\text { Glucose, } m M / \text { liter } \\
\quad P\end{array}$ & $4.56 \pm 0.11$ & $\begin{array}{l}6.56 \pm 0.78 \\
<0.05\end{array}$ & $\begin{array}{l}7.67 \pm 0.33 \\
<0.001\end{array}$ & $\begin{array}{c}8.67 \pm 0.67 \\
<0.001\end{array}$ & $\begin{array}{l}8.22 \pm 0.78 \\
<0.001\end{array}$ & $\begin{array}{l}7.50 \pm 0.83 \\
<0.005\end{array}$ & $\begin{array}{l}6.44 \pm 0.83 \\
<0.01\end{array}$ \\
\hline $\begin{array}{l}\mathrm{K}, \text { meq/liter } \\
P\end{array}$ & $4.0 \pm 0.1$ & $4.0 \pm 0.1$ & $\begin{array}{r}3.8 \pm 0.1 \\
<0.001\end{array}$ & $\begin{array}{r}3.7 \pm 0.1 \\
<0.001\end{array}$ & $\begin{array}{c}3.7 \pm 0.1 \\
<0.01\end{array}$ & $\begin{array}{r}3.6 \pm 0.1 \\
<0.001\end{array}$ & $\begin{array}{r}3.6 \pm 0.1 \\
<0.005\end{array}$ \\
\hline $\begin{array}{l}\text { Total Ca, } m M / \text { liter } \\
\quad P\end{array}$ & $2.28 \pm 0.03$ & $2.25 \pm 0.04$ & $\begin{array}{l}2.22 \pm 0.04 \\
<0.005\end{array}$ & $\begin{array}{l}2.22 \pm 0.03 \\
<0.001\end{array}$ & $\begin{array}{l}2.20 \pm 0.03 \\
<0.005\end{array}$ & $\begin{array}{l}2.18 \pm 0.03 \\
<0.001\end{array}$ & $\begin{array}{l}2.18 \pm 0.04 \\
<0.001\end{array}$ \\
\hline $\begin{array}{l}\mathrm{Cl}, \text { meq/liter } \\
P\end{array}$ & $101 \pm 1$ & $101 \pm 1$ & $\begin{array}{r}102 \pm 1 \\
<0.02\end{array}$ & $\begin{array}{l}102 \pm 1 \\
<0.002\end{array}$ & $\begin{array}{l}103 \pm 1 \\
<0.001\end{array}$ & $\begin{array}{l}103 \pm 1 \\
<0.001\end{array}$ & $\begin{array}{l}104 \pm 1 \\
<0.002\end{array}$ \\
\hline $\mathrm{P}, \underset{P}{m} M /$ liter & $1.15 \pm 0.05$ & $1.13 \pm 0.04$ & $\begin{array}{l}1.07 \pm 0.06 \\
<0.005\end{array}$ & $\begin{array}{c}1.02 \pm 0.05 \\
<0.001\end{array}$ & $\begin{array}{l}0.98 \pm 0.05 \\
<0.001\end{array}$ & $\begin{array}{l}0.96 \pm 0.04 \\
<0.001\end{array}$ & $\begin{array}{l}0.91 \pm 0.04 \\
<0.001\end{array}$ \\
\hline $\begin{array}{l}\text { Osmolality, mosmol } / k g \\
\quad P\end{array}$ & $285 \pm 2$ & $287 \pm 3$ & $288 \pm 3$ & $\begin{array}{r}290 \pm 3 \\
<0.05\end{array}$ & $288 \pm 2$ & $287 \pm 2$ & $287 \pm 2$ \\
\hline $\begin{array}{l}\text { Urea, } m M / \text { liter } \\
\quad P\end{array}$ & $4.2 \pm 0.4$ & $\begin{array}{r}4.0 \pm 0.4 \\
<0.001\end{array}$ & $\begin{array}{r}3.9 \pm 0.3 \\
<0.001\end{array}$ & $\begin{array}{r}3.7 \pm 0.3 \\
<0.001\end{array}$ & $\begin{array}{r}3.6 \pm 0.3 \\
<0.001\end{array}$ & $\begin{array}{c}3.5 \pm 0.3 \\
<0.001\end{array}$ & $\begin{array}{c}3.4 \pm 0.4 \\
<0.001\end{array}$ \\
\hline
\end{tabular}


statistically significant only during the escape studies. $\mathrm{C}_{\mathrm{H}_{2} \mathrm{O}} / \mathrm{V}$ did not change after glucose loading either before or after chronic ECF volume expansion.

\section{DISCUSSION}

When glucose is ingested or infused intravenously with insulin, renal tubular reabsorption of calcium and magnesium becomes inhibited $(1,2)$. Other rapidly metabolizable substrates also induce this effect (1). The mechanism that causes this response and the site(s) along the nephron where it occurs have been obscure. The present studies, taken with recent observations of the role of glucose and amino acids in the generation of transtubular electrical potentials (14), offer a possible explanation.
In earlier studies of glucose-induced calciuria and magnesuria, we attempted to draw inferences about possible tubular sites at which calcium and magnesium reabsorption are inhibited by reference to simultaneous effects on sodium reabsorption. During water diuresis, changes in the relationship between sodium and water reabsorption can be used to indicate changes in sodium reabsorption in the proximal tubule and at diluting sites, while changes in acid and potassium excretion yield information about the activity of distal tubular cation exchange. No similar indirect means of evaluating segmental' calcium and magnesium reabsorption are available. By such analogies, we have argued that the inhibition of tubular calcium and magnesium reabsorption that follows glucose loading might be a distal effect (3). Net tubular sodium reabsorption is consistently aug-

TABLE V

Urine Composition before and after Glucose during Control Clearances

\begin{tabular}{|c|c|c|c|c|c|c|c|}
\hline & Control mean & 1 & 2 & 3 & 4 & 5 & 6 \\
\hline $\mathrm{V}, \mathrm{ml} / \min$ & $13.8 \pm 1.0$ & $13.2 \pm 1.2$ & $11.6 \pm 1.3$ & $11.7 \pm 1.3$ & $13.1 \pm 0.8$ & $14.0 \pm 1.4$ & $17.3 \pm 0.9$ \\
\hline $\mathrm{U}_{\mathrm{Osm}}, \mathrm{mosmol} / \mathrm{kg}$ & $63 \pm 4$ & $71 \pm 6$ & $82 \pm 21$ & $73 \pm 13$ & $58 \pm 3$ & $71 \pm 13$ & $52 \pm 2$ \\
\hline $\mathrm{U}_{\mathrm{Na}} \mathrm{V}, \mu M / \min$ & $141 \pm 18$ & $169 \pm 22$ & $112 \pm 12$ & $108 \pm 10$ & $110 \pm 10$ & $138 \pm 16$ & $165 \pm 11$ \\
\hline $\begin{array}{l}\mathrm{U}_{\mathrm{K}} \mathrm{V}, \mu M / \min \\
\quad P\end{array}$ & $76 \pm 8$ & $67 \pm 5$ & $\begin{array}{l}39 \pm 3 \\
<0.002\end{array}$ & $\begin{array}{l}31 \pm 3 \\
<0.001\end{array}$ & $\begin{array}{l}27 \pm 2 \\
<0.001\end{array}$ & $\begin{array}{l}30 \pm 2 \\
<0.001\end{array}$ & $\begin{array}{l}30 \pm 3 \\
<0.001\end{array}$ \\
\hline $\begin{array}{l}\mathrm{U}_{\mathrm{Ca}} \mathrm{V}, \mu M / \min \\
\quad P\end{array}$ & $3.02 \pm 0.56$ & $\begin{array}{l}3.69 \pm 0.74 \\
<0.05\end{array}$ & $\begin{array}{c}4.26 \pm 0.78 \\
<0.001\end{array}$ & $\begin{array}{c}5.34 \pm 1.00 \\
<0.005\end{array}$ & $\begin{array}{c}5.67 \pm 0.88 \\
<0.001\end{array}$ & $\begin{array}{c}6.08 \pm 0.75 \\
<0.001\end{array}$ & $\begin{array}{l}6.00 \pm 1.10 \\
<0.02\end{array}$ \\
\hline $\begin{array}{l}\mathrm{U}_{\mathbf{M g}_{\mathrm{g}} \mathrm{V}, \mu M / \min } \\
P\end{array}$ & $3.09 \pm 0.43$ & $\begin{array}{l}3.63 \pm 0.52 \\
<0.05\end{array}$ & $\begin{array}{l}4.41 \pm 0.55 \\
<0.001\end{array}$ & $\begin{array}{c}5.41 \pm 0.78 \\
<0.005\end{array}$ & $\begin{array}{l}6.22 \pm 0.75 \\
<0.001\end{array}$ & $\begin{array}{c}5.99 \pm 0.79 \\
<0.005\end{array}$ & $\begin{array}{l}4.75 \pm 0.78 \\
<0.02\end{array}$ \\
\hline $\begin{array}{l}\mathrm{H}^{+}, \text {neq/liter } \\
\quad P\end{array}$ & $354 \pm 70$ & $395 \pm 75$ & $\begin{array}{c}574 \pm 100 \\
<0.005\end{array}$ & $\begin{array}{r}633 \pm 94 \\
<0.002\end{array}$ & $\begin{array}{l}715 \pm 138 \\
<0.05\end{array}$ & $\begin{array}{c}605 \pm 85 \\
<0.01\end{array}$ & $485 \pm 103$ \\
\hline $\mathrm{pH}$ & 6.45 & 6.40 & 6.24 & 6.20 & 6.15 & 6.22 & 6.31 \\
\hline $\begin{array}{l}\mathrm{U}_{\mathrm{HCO}_{3}} \mathrm{~V}, \mu e q / \min \\
\quad P\end{array}$ & $38 \pm 9$ & $35 \pm 8$ & $\begin{array}{l}19 \pm 5 \\
<0.05\end{array}$ & $\begin{array}{l}16 \pm 3 \\
<0.05\end{array}$ & $15 \pm 2$ & $20 \pm 4$ & $30 \pm 6$ \\
\hline $\begin{array}{l}\mathrm{U}_{\mathrm{NH}_{4}}+\mathrm{V}, \mu e q / \min \\
P\end{array}$ & $38 \pm 3$ & $39 \pm 4$ & $\begin{array}{l}48 \pm 4 \\
<0.002\end{array}$ & $\begin{array}{l}49 \pm 4 \\
<0.005\end{array}$ & $\begin{array}{l}46 \pm 3 \\
<0.001\end{array}$ & $\begin{array}{l}47 \pm 3 \\
<0.01\end{array}$ & $\begin{array}{l}47 \pm 4 \\
<0.01\end{array}$ \\
\hline $\begin{array}{l}\mathrm{U}_{\mathrm{TA}} \mathrm{V}, \mu e q / \min \\
\quad P\end{array}$ & $6 \pm 1$ & $\begin{array}{r}9 \pm 2 \\
<0.02\end{array}$ & $\begin{array}{l}12 \pm 1 \\
<0.001\end{array}$ & $\begin{array}{l}11 \pm 1 \\
<0.02\end{array}$ & $9 \pm 1$ & $9 \pm 2$ & $7 \pm 1$ \\
\hline $\begin{array}{l}\mathrm{U}_{\mathrm{Net}} \mathrm{Acid} \mathrm{V}, \mu e q / \min \\
\quad P\end{array}$ & $+6 \pm 11$ & $+13 \pm 11$ & $\begin{array}{r}+41 \pm 8 \\
<0.01\end{array}$ & $\begin{array}{r}+43 \pm 5 \\
<0.01\end{array}$ & $\begin{array}{r}+40 \pm 4 \\
<0.02\end{array}$ & $\begin{array}{r}+36 \pm 6 \\
<0.05\end{array}$ & $\begin{array}{r}+24 \pm 9 \\
<0.05\end{array}$ \\
\hline $\begin{array}{l}\mathrm{U}_{\mathrm{Cl}} \mathrm{V}, \mu M / \min \\
\quad P\end{array}$ & $154 \pm 18$ & $168 \pm 20$ & $111 \pm 13$ & $\begin{array}{c}108 \pm 12 \\
<0.05\end{array}$ & $114 \pm 14$ & $140 \pm 19$ & $159 \pm 14$ \\
\hline $\begin{array}{l}\mathrm{U}_{\mathrm{PO}_{4}} \mathrm{~V}, \mu M / \min \\
\quad P\end{array}$ & $12.4 \pm 1.1$ & $\begin{array}{l}18.8 \pm 2.0 \\
<0.02\end{array}$ & $\begin{array}{r}21.0 \pm 1.2 \\
<0.001\end{array}$ & $18.1 \pm 2.4$ & $15.4 \pm 2.9$ & $14.8 \pm 3.3$ & $12.6 \pm 3.0$ \\
\hline $\mathrm{U}_{\text {Glucose }} \mathrm{V}, \mu M / \min$ & $0.52 \pm 0.05$ & $29 \pm 16$ & $6.4 \pm 3.1$ & $16 \pm 6$ & $30 \pm 13$ & $39 \pm 19$ & $19 \pm 11$ \\
\hline $\mathrm{U}_{\mathrm{Osm}} \mathrm{V}, \mu \mathrm{osmol} / \mathrm{min}$ & $849 \pm 55$ & $905 \pm 84$ & $757 \pm 46$ & $733 \pm 35$ & $735 \pm 41$ & $844 \pm 39$ & $880 \pm 24$ \\
\hline $\mathrm{U}_{\mathrm{Urea}} \mathrm{V}, \mu M / \min$ & $339 \pm 25$ & $329 \pm 28$ & $333 \pm 24$ & $330 \pm 19$ & $320 \pm 25$ & $336 \pm 22$ & $343 \pm 30$ \\
\hline $\mathrm{U}_{\mathrm{sO}_{4}} \mathrm{~V}, \mu e q / \min$ & $25 \pm 2$ & $27 \pm 3$ & $25 \pm 2$ & $28 \pm 1$ & $26 \pm 1$ & $27 \pm 2$ & $26 \pm 2$ \\
\hline $\mathrm{U}_{\mathrm{OA}} \mathrm{V}, \mu e q / \min$ & $97 \pm 10$ & $104 \pm 15$ & $98 \pm 14$ & $100 \pm 14$ & $111 \pm 17$ & $117 \pm 19$ & $127 \pm 21$ \\
\hline $\begin{array}{r}\mathrm{C}_{\mathrm{IN}} \\
P\end{array}$ & $113 \pm 4$ & $114 \pm 6$ & $118 \pm 8$ & $120 \pm 7$ & $118 \pm 6$ & $\begin{array}{r}128 \pm 6 \\
<0.05\end{array}$ & $\begin{array}{r}128 \pm 4 \\
<0.05\end{array}$ \\
\hline
\end{tabular}




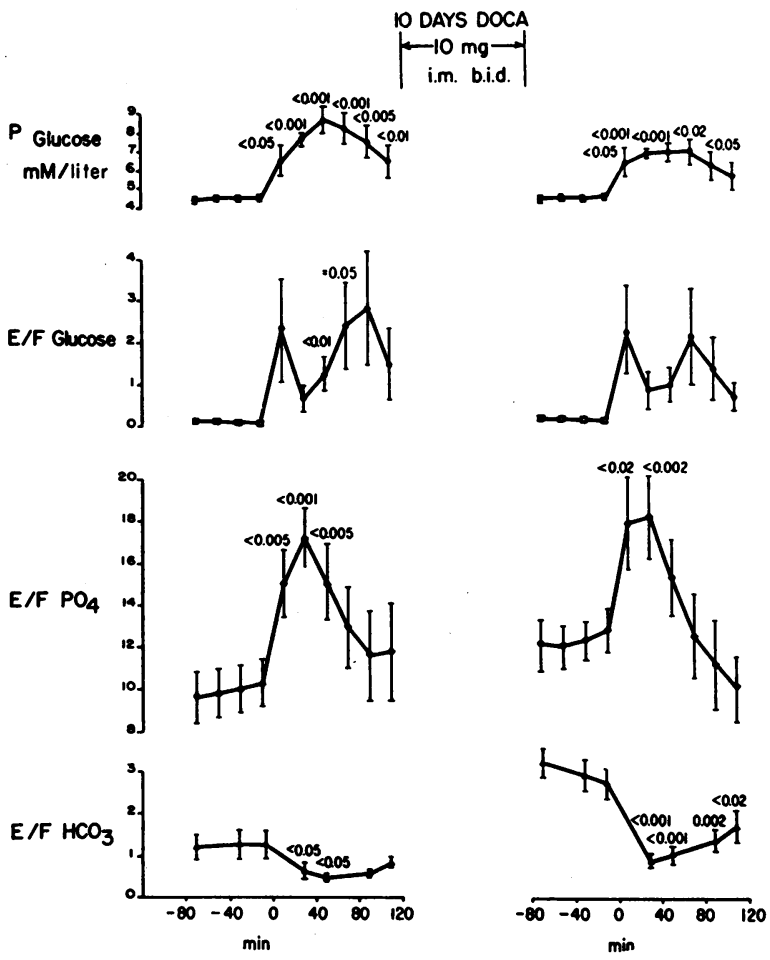

Figure 3 Mean plasma glucose concentrations and fractional excretion rates of glucose, phosphate, and bicarbonate during clearances before and after DOCA escape. Glucose administered at zero time in both studies. Vertical lines indicate \pm SEM. $P$ values are for mean of individual changes from control after glucose.

mented by a glucose load, and previous studies suggested that this was the result of increased fractional reabsorption in the proximal tubule (4). In many physiological circumstances, proximal reabsorption of sodium, calcium, and magnesium appear to vary directly $(15,16)$. On the other hand, the sum of urinary potassium and acid excretion falls after glucose loading (Fig. 2), suggesting inhibition of sodium reabsorption at the distal cation exchange site. We speculated that glucose loading might also inhibit calcium and magnesium reabsorption at this distal site. Significant correlation between increments in urinary calcium and magnesium excretion and increments in organic acid excretion led us to question whether increased capillary delivery of glucose and its subsequent metabolism by distal nephron segments might alter cell energetics and somehow inhibit cation transport $(3,4)$. The results of the present study do not exclude this possibility and, indeed, distal inhibition of calcium and magnesium reabsorption may be one effect of glucose loading.

The present studies were designed to permit a more critical evaluation of the effects of glucose loads on fractional reabsorption by the proximal tubule. Chronic mineralocorticoid excess induces initial sodium retention, followed by escape from this effect, attributed to the development of inhibition of sodium reabsorption at proximal and/or distal tubular sites $(11,17)$. Mineralocorticoid excess also-induces a progressive rise in urinary calcium excretion that continues after the escape phenomenon (18). We observed the responses to glucose loads in normal men before beginning DOCA administration and after escape from its sodium-retaining action. The design of the study allowed us to examine the effects of DOCA administration alone on urinary composition and tubular function. The escape from DOCA-induced sodium retention, as observed in the 24-h urine collections, was accompanied by a progressive rise in calcium excretion, no change in phosphorus excretion, and a return of urine volume and sodium excretion rates to control levels. We also found no change in magnesium excretion. Hypomagnesemia and magnesuria occur commonly in patients with primary hyperaldosteronism. We have no explanation for this discrepancy, but would speculate that the duration of mineralocorticoid excess may play a role. Since phosphorus is believed to be reabsorbed primarily in the proximal tubule, the failure to find any increase in phosphorus excretion during escape suggests that fractional proximal reabsorption was not inhibited, as others have proposed

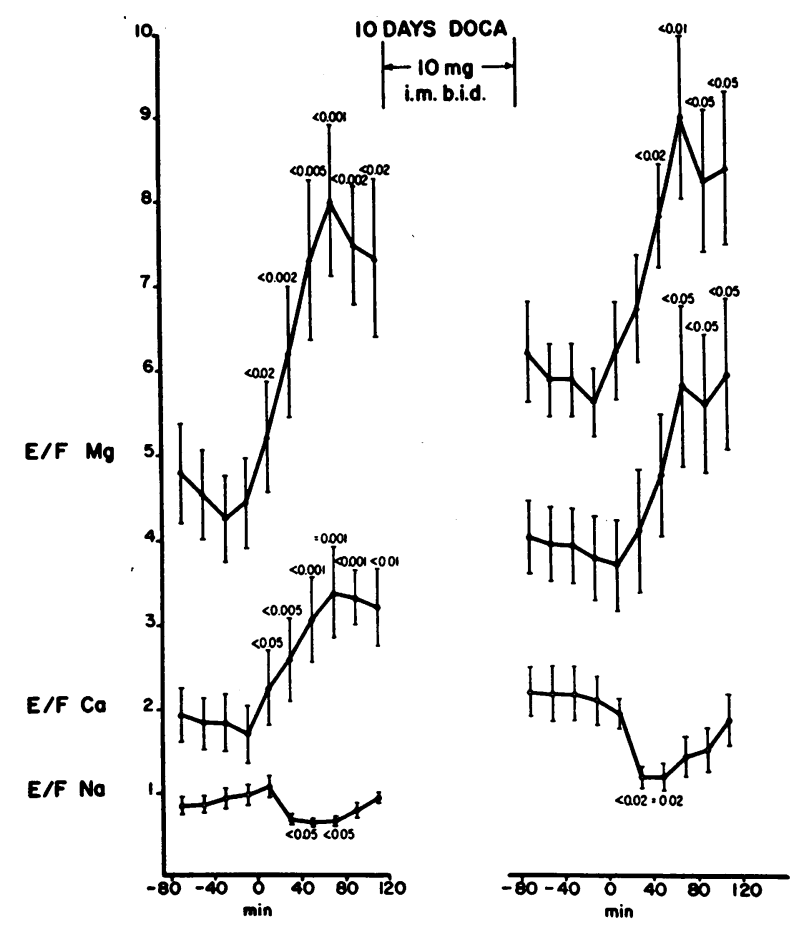

Figure 4 Mean fractional excretion rates of sodium, calcium, and magnesium during clearances before and after DOCA escape. Glucose administered at zero time. 

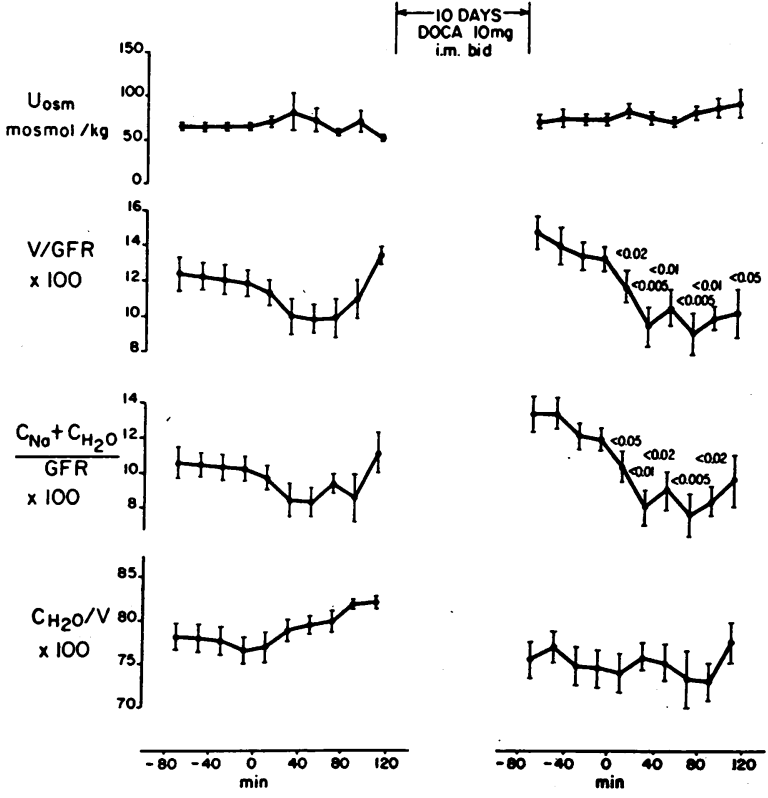

FigURE 5 Mean urinary osmolality, V/GFR, $\mathrm{C}_{\mathrm{Na}_{\mathrm{a}}}+\mathrm{C}_{\mathrm{H}_{2} \mathrm{O}} /$ GFR, and $\mathrm{C}_{\mathrm{H}_{2} \mathrm{O}} / \mathrm{V}$ during clearances before and after DOCA escape. Glucose administered at zero time.

(18). By contrast, when we compared the clearance periods before glucose administration during the normal steady state with these same periods after DOCA escape, chronic volume expansion appeared to inhibit fractional proximal reabsorption significantly, as reported by Alexander, Doner, Auld, and Levinsky (11). This was suggested by significant increases in $\mathrm{Curea}_{\text {ar }} / \mathrm{GFR}$ and in $\mathrm{V} / \mathrm{GFR}, \mathrm{C}_{\mathrm{N} 2}+\mathrm{C}_{\mathrm{H}_{2} \mathrm{O}} / \mathrm{GFR}$, and urinary phosphorus and glucose excretion. $\mathrm{V}, \mathrm{U}_{\mathrm{Na}} \mathrm{V}$, and $\mathrm{U}_{\mathbf{M g}_{\mathrm{g}} \mathrm{V}}$ were also significantly increased, although they were not above control rates in the 24-h urine collections. These discrepancies cause us to question whether the observed fall in fractional proximal reabsorption evident in the clearance measurements may not have been the result of an exaggerated response to water loading during chronic volume expansion, rather than a direct expression of the mechanism causing escape from DOCA-induced sodium retention. Since $\mathrm{C}_{\mathrm{H}_{2} \mathrm{O}} / \mathrm{V}$ did not change after escape, an absolute reduction in distal sodium reabsorption could not be inferred. ${ }^{2}$

Glucose administration resulted in augmented proximal tubular reabsorption of sodium both before and after DOCA escape, as inferred from reductions in $\mathrm{V} / \mathrm{GFR}$ and $\mathrm{C}_{\mathrm{Na}}+\mathrm{C}_{\mathrm{H}_{2} \mathrm{O}} / \mathrm{GFR}$. This was most striking

${ }^{2}$ Since $\mathrm{C}_{\mathrm{H}_{2} \mathrm{O}} / \mathrm{V}$ is dependent upon distal sodium delivery (19), failure to find changes in $\mathrm{C}_{\mathrm{H}_{2} \mathrm{O}} / \mathrm{V}$ when distal delivery was increased (e.g. after DOCA escape), or decreased, (e.g. after glucose loading), might indicate relative inhibition and augmentation of sodium reabsorption at the diluting site, respectively. after DOCA escape. No change in fractional sodium reabsorption in diluting segments was apparent in either circumstance, since $\mathrm{C}_{\mathrm{H}_{2} \mathrm{O}} / \mathrm{V}$ was not affected. ${ }^{2}$ These results with respect to changes in segmental tubular sodium reabsorption after glucose agree with earlier studies in subjects starved for days $(5,6)$. In the normal steady state, glucose administration was followed by a fall in the sum of urinary net acid and potassium excretion, as previously described (4). After escape from DOCA, the striking fall in bicarbonate excretion after glucose administration precluded estimation of the activity of the distal cation exchange site, since we could not distinguish between augmented proximal reabsorption of $\mathrm{NaHCO}_{3}$ (via $\mathrm{H}^{+}$secretion) and distal bicarbonate titration. It is well known that glucose competes with phosphate for proximal tubular reabsorption (20). Thus the marked fall in fractional tubular reabsorption of phosphate after glucose loading can be accounted for on the basis of this effect and does not contradict the other evidence cited for augmented proximal reabsorption of sodium and water.

There was significant correlation between the increments in urinary organic acid and $\mathrm{Uca}_{\mathrm{ca}}(r=+0.45$, $P=0.001)$ and $\mathrm{U}_{\mathbf{M g}_{\mathrm{g}} \mathrm{V}}(r=+0.52, P=0.001)$ after glucose loading both before and after DOCA escape. The augmented excretion rates of calcium and magnesium after glucose loading were similar before and after DOCA escape and were simply additive to the effects of chronic volume expansion alone.

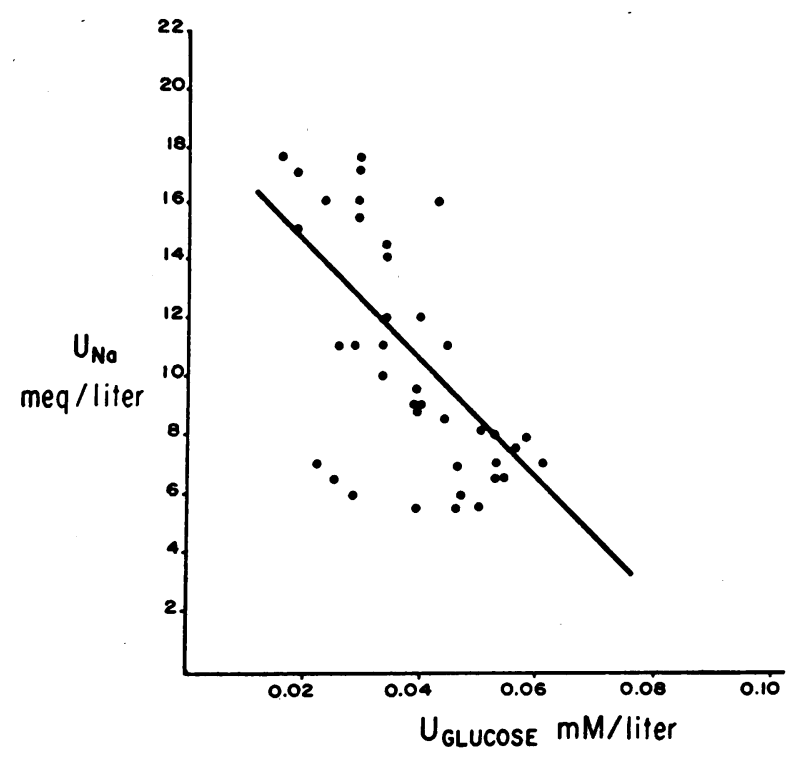

FIGURE 6 Correlation of urinary sodium and glucose concentrations for control clearance periods before DOCA (see text). $\left[\mathrm{U}_{\mathrm{Na}}\right] \mathrm{meq} / \mathrm{liter}=18.3-211\left[\mathrm{U}_{\mathrm{G}}\right] \mathrm{mM} /$ liter. $r=-0.65, P<0.001$. 

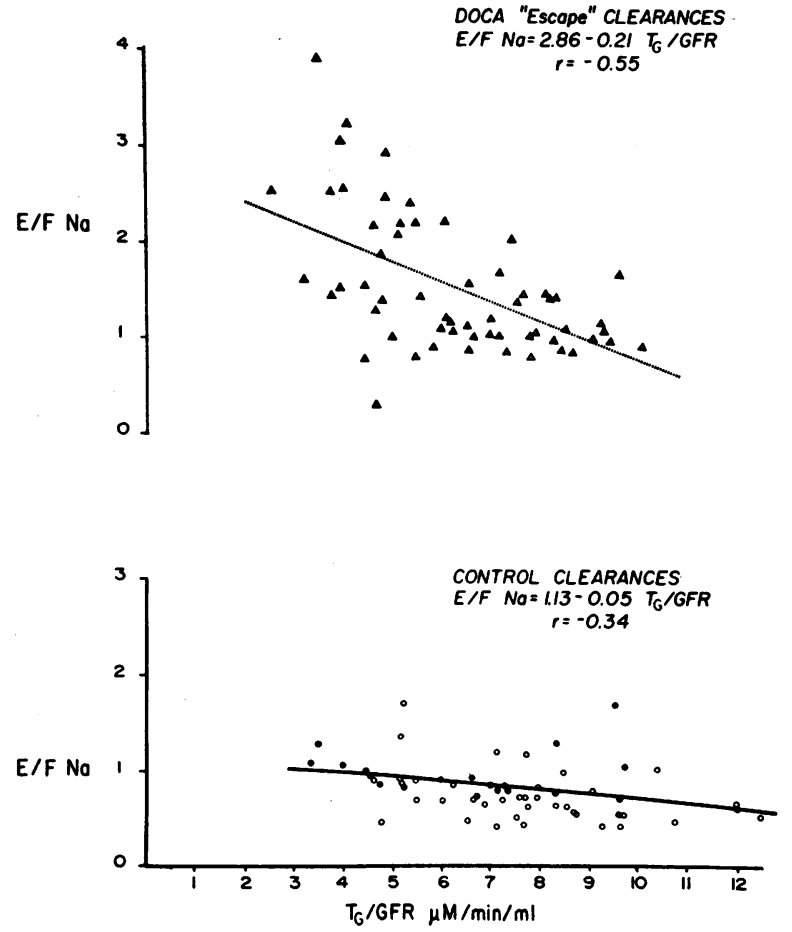

FIGURE 7 Correlation of fractional sodium excretion with fractional glucose reabsorption during the experimental clearance periods before and after DOCA escape. Open symbols indicate subjects given oral glucose. Closed symbols indicate subjects given glucose and insulin intravenously.

Correlations between tubular glucose and sodium reabsorption were evident both before and after glucose administration and these relationships were altered by chronic volume expansion. At normal rates of glucose filtration (i.e. before glucose loading) urinary sodium concentrations $\left(U_{\mathrm{Na}}\right.$ ) were an inverse linear function of urinary glucose concentrations $\left(U_{G}\right)$ as shown for the studies before volume expansion in Fig. 6. This finding was confirmed in 12 additional control clearance studies in 7 other normal men $\left(\mathrm{U}_{\mathrm{Na}} \mathrm{meq} / \mathrm{liter}=16.8-136 \mathrm{U}_{\mathrm{a}}\right.$ $\mathrm{mM} /$ liter ; $r=-0.56$ ). Since glucose is largely reabsorbed in the proximal tubule (21), Ua during brisk water diuresis should reflect the minimal concentration of glucose present in the most distal portions of the proximal tubule. Furthermore, since both absolute tubular glucose reabsorption $\left(\mathrm{T}_{\mathrm{a}}\right)$ and urinary glucose excretion vary directly with the rate of glucose filtration (22), $U_{a}$ should be directly related to $T_{a}$ during stable water diuresis. If sodium reabsorption at other tubular sites was relatively stable and unaffected by tubular fluid glucose concentrations, these data are consistent with the hypothesis that proximal tubular sodium reabsorption is facilitated by glucose reabsorption, even at these low glucose concentrations. During chronic volume expansion, but before glucose loading, $U_{\mathrm{Na}}$ was more variable, but tended to be higher at any given $U_{G}$ $\left(\mathrm{U}_{\mathrm{Na}} \mathrm{meq} / \mathrm{liter}=32-152 \mathrm{U}_{\mathrm{G}} \mathrm{mM} / \mathrm{liter} ; r=-0.29\right)$.

After glucose administration in the normal steady state, $U_{G}$ varied widely $(0.044-8.2 \mathrm{mM} /$ liter $)$ despite which $U_{\mathrm{Na}}$ tended to stabilize at a somewhat reduced level $(8.5 \pm 0.2 \mathrm{meq} / \mathrm{liter})$, suggesting that sufficient glucose was present within the tubular fluid to permit attainment of a minimum sodium concentration. Glucose loading during chronic volume expansion yielded similar variations in $\mathrm{U}_{\mathrm{a}}(0.05$ to $11.1 \mathrm{mM} / \mathrm{liter})$, while $\mathrm{U}_{\mathrm{Na}}$ stabilized at $19.5 \pm 1.1 \mathrm{meq} / \mathrm{liter}$, a value more than twice as high as that found before expansion, presumably reflecting the separate inhibiting effect of chronic volume expansion on sodium reabsorption.

The variations in fractional glucose reabsorption $\left(T_{a} / G F R\right)$ which followed glucose loading were inversely correlated with fractional sodium excretion $\left(\mathrm{C}_{\mathrm{Na}} / 100 \mathrm{ml}\right.$ GFR $)$ as illustrated in Fig. 7, separately for the clearances before and after DOCA escape. This relationship was also examined for each subject by calculation of the slope of the individual regressions of $\mathrm{E} / \mathrm{F}$ $\mathrm{Na}$ on $\mathrm{T}_{a} / \mathrm{GFR}$. For the studies before DOCA the mean slope for the group was not significantly different from zero $(-0.05 \pm 0.02 ; 0.1>P>0.05)$. For the studies after DOCA escape, the mean slope was negative and significantly different from zero $(-0.23 \pm 0.07 ; P<0.01)$. Kurtzman, White, Rogers, and Flynn found a similar inverse correlation in dogs infused with glucose at rates sufficient to insure that at least $50 \%$ of filtered glucose was excreted when $\mathrm{C}_{\mathrm{Na}} / 100 \mathrm{ml}$ GFR was caused to vary by acute volume expansion or constriction of the inferior vena cava (22). Perfusion of proximal tubules of the newt kidney with glucose-containing solutions produces a concentration-related increase in transtubular potential difference, lumen negative, consistent with augmentation of active sodium transport (23). More recently, Kokko (14) has shown that isolated rabbit proximal tubules perfused with solutions containing glucose, alanine, and bicarbonate (as well as $\mathrm{NaCl}$ ) have a mean potential difference of $-5.8 \pm 0.2 \mathrm{mV}$ (lumen negative). When glucose and alanine were omitted from the perfusate and the $\mathrm{HCO}_{3}^{-}$concentration reduced to $5.6 \mathrm{meq} / \mathrm{liter}$, the potential difference changed to a mean of $+3.2 \pm 0.2$ $\mathrm{mV}$. Such conditions have been shown to exist beyond the earlier portion of the proximal tubule of rats (24). The positive potential difference existing beyond the early proximal tubule appears to result from a chloride diffusion potential and would be expected to facilitate the reabsorption of cations. Based on Kokko's model, it is conceivable that increasing glucose (or amino acid) delivery to the proximal tubule might allow glucose (or amino acid) absorption to proceed along a longer seg- 
ment of the proximal tubule, augmenting sodium reabsorption and, by delaying the development of positive potential difference, inhibiting the reabsorption of other cations, such as calcium and magnesium. Since the net flux of ions in a given electrical field is an exponential function of their valence, persistence of the negative potential difference would have a greater effect on the passive reabsorption of divalent cations as compared to univalent cations (25). Clearly, this hypothesis would require that the delay of the appearance of a positive potential difference override the opposing effects of rising intratubular calcium and magnesium concentrations and the longer time of contact with the absorbing membrane, expected as a result of increased fractional reabsorption of sodium (and water). Micropuncture data will be required to test this possibility critically.

\section{ACKNOWLEDGMENTS}

We are grateful for the skilled assistance of Miss Opal Kelly, together with the nursing and technical staffs of The Medical College of Wisconsin Clinical Research Center. This work was supported by U. S. Public Health Service Grants AM 15089 and RR 00058.

\section{REFERENCES}

1. Lindeman, R. D., S. Adler, M. J. Yiengst, and E. S. Beard. 1967. Influence of various nutrients on urinary divalent cation excretion. J. Lab. Clin. Med. 70: 236.

2. Lemann, J., Jr., W. F. Piering, and E. J. Lennon. 1969. Possible role of carbohydrate-induced calciuria in calcium oxalate kidney-stone formation. N. Engl. J. Med. 280: 232.

3. Lemann, J., Jr., E. J. Lennon, W. F. Piering, E. L. Prien, Jr., and E. S. Ricanati. 1970. Evidence that glucose inhibits net renal tubular reabsorption of calcium and magnesium in man. J. Lab. Clin. Med. 75: 578.

4. Lennon, E. J., and W. F. Piering. 1970. A comparison of the effects of glucose ingestion and $\mathrm{NH}_{4} \mathrm{Cl}$ acidosis on urinary calcium and magnesium excretion in man. J. Clin. Invest. 49: 1458.

5. Hoffman, R. S., J. A. Martino, G. Wahl, and R. A. Arky. 1969. Effects of fasting and refeeding. II. Tubular sites of sodium reabsorption and effects of oral carbohydrate on potassium, calcium, and phosphate excretion. J. Lab. Clin. Med. 74: 915.

6. Schloeder, F. X., and B. J. Stinebaugh. 1970. Renal tubular sites of natriuresis of fasting and glucose-induced sodium conservation. Metab. (Clin. Exp.). 19: 1119.

7. Walser, M. 1961. Calcium clearance as a function of sodium clearance in the dog. Am. J. Physiol. 200: 1099.

8. Massry, S. G., J. W. Coburn, L. W. Chapman, and C. R. Kleeman. 1967. Effect of $\mathrm{NaCl}$ infusion on urinary $\mathrm{Ca}^{++}$and $\mathrm{Mg}^{++}$during reduction in their filtered loads. Am. J. Physiol. 213 : 1218.

9. Blythe, W. J., H. J. Gitelman, and L. G. Welt. 1968. Effect of expansion of extracellular space on the rate of urinary excretion of calcium. Am. J. Physiol. 214: 52.

10. Massry, S. G., J. W. Coburn, L. W. Chapman, and C. R. Kleeman. 1968. The effect of long-term desoxycorticosterone acetate administration on the renal excretion of calcium and magnesium. J. Lab. Clin. Med. $71: 212$.

11. Alexander, E. A., D. W. Doner, Jr., R. B. Auld, and N. G. Levinsky. 1973. Tubular reabsorption of sodium during acute and chronic volume expansion in man. $J$. Clin. Invest. 51 : 2370.

12. Logan, J. E., and D. E. Haight. 1965. Enzymatic determination of glucose in urine by automation following rapid removal of inhibitors by ion-exchange resin. Clin. Chem. Acta. 11 : 367.

13. Lemann, J., Jr., J. R. Litzow, and E. J. Lennon. 1967. Studies of the mechanism by which chronic metabolic acidosis augments urinary calcium excretion in man. J. Clin. Invest. 46: 1318.

14. Kokko, J. P. 1973. Proximal tubule potential difference. Dependence on glucose, $\mathrm{HCO}_{3}$, and amino acids. J. Clin. Invest. 52 : 1362.

15. Duarte, C. G., and J. F. Watson. 1967. Calcium reabsorption in proximal tubule of the dog nephron. $\mathrm{Am}$. J. Physiol. 212: 1355.

16. Brunette, M., S. F. Wen, R. L. Evanson, and J. H. Dirks. 1969. Micropuncture study of magnesium reabsorption in the proximal tubule of the dog. $A m$. J. Physiol. 216: 1510.

17. Willis, L. R., E. G. Schneider, R. E. Lynch, and F. G. Knox. 1972. Effect of chronic alteration of sodium balance on reabsorption by proximal tubule of the dog. Am. J. Physiol. 223 : 34.

18. Rastegar, A., Z. Agus, T. B. Connor, and M. Goldberg. 1972. Renal handling of calcium and phosphate during mineralocorticoid "escape" in man. Kidney Int. 2: 279.

19. Buckalew, V. M., Jr., B. R. Walker, J. B. Puschett, and M. Goldberg. 1970. Effects of increased sodium delivery on distal tubular sodium reabsorption with and without volume expansion in man. J. Clin. Invest. $49: 2336$.

20. Pitts, R. F. 1968. Physiology of the Kidney and Body Fluids. Year Book Medical Publishers Inc., Chicago, Ill. 2nd edition. 78.

21. Baines, A. D., and J. H. V. Bishop. 1971. Effect of extracellular fluid volume expansion on maximum glucose reabsorption rate and glomerular tubular balance in single rat nephrons. J. Clin. Invest. 50: 2414.

22. Kurtzman, N. A., M. G. White, P. W. Rogers, and J. J. Flynn. 1972. Relationship of sodium reabsorption and glomerular filtration rate to renal glucose reabsorption. J. Clin. Invest. 51: 127.

23. Maruyama, T., and T. Hoshi. 1972. The effect of dglucose on the electrical potential profile across the proximal tubule of Newt kidney. Biochim. Biophys. Acta. $282: 214$.

24. Chirito, E., and J. F. Seely. 1973. Evidence for a change in potential difference along the length of the rat proximal tubule in vivo: the role of chloride. Clin. Res. 21: 680 .

25. Brown, A. C. 1965. Passive and active transport. In Physiology and Biophysics. T. C. Ruch and H. D. Patton, editors. W. B. Saunders Company, Philadelphia. 19th edition. 838 . 